\title{
CCR4-NOT Transcription Complex Subunit
} 3

National Cancer Institute

\section{Source}

National Cancer Institute. CCR4-NOT Transcription Complex Subunit 3. NCI Thesaurus. Code C107660.

CCR4-NOT transcription complex subunit 3 (753 aa, $~ 82 \mathrm{kDa}$ ) is encoded by the human CNOT 3 gene. This protein is involved in transcriptional regulation, RNA processing and translational regulation. 